\title{
Arte Urbana Collectif and Bulgarian film education: An interview with rural classroom teacher Daniel Simeonov
}

\author{
Ralitsa Assenova* - National Academy for Theatre and Film Arts, Bulgaria \\ Translated from Bulgarian by Yoana Pavlova and Daniel Simeonov
}

\begin{abstract}
While arts education is not currently prioritized by Bulgaria's conservative educational administration, non-governmental organizations such as Arte Urbana Collectif are pursuing a series of initiatives and projects in film education, geared specifically towards bringing together teachers and professionals. Here, we present an interview with Daniel Simeonov, a teacher at Neofit Rilski primary school, a small rural school in Dermantsi that has been collaborating with Arte Urbana Collectif on a film education project exploring both analysis and practice. Students are introduced to the art of cinema first, as spectators, watching films in their entirety and exploring first steps towards film analysis. Subsequently, they are placed in the active position of creating and directing a short film. Here, we establish a context for Arte Urbana Collectif's work within a broader history of film education in Bulgaria, before going on to explore both pedagogical and societal perspectives arising from the project through an interview conducted with Daniel Simeonov by Arte Urbana Collectif co-founder Ralitsa Assenova.
\end{abstract}

Keywords: film education; social inclusion; youth; media literacy; transmitting cinema in school

The Lesson (2014), the first feature film of Bulgarian directors Kristina Grozeva and Petar Valchanov, features a notable scene in which a class of young children collects money to buy breakfast for a student whose wallet has been stolen. The teacher asks each student to put 10 stotinki (5 cents) on her desk, before being approached by one of the children who quietly tells her, 'Miss, I don't have any.'

This scene finds an unfortunate resonance within many rural education settings across Bulgaria, which continue to face considerable socio-economic challenges. A notable number of school buildings in small towns and villages require a significant degree of infrastructural work. While this crucial renovation work has begun to be addressed to some extent by the Ministry of Education and local authorities, the access to culture in underprivileged school settings across Bulgaria remains very limited, and focused mainly upon folklore lessons. The question thus presents itself: if in some schools there is as yet no adequate heating in the winter, should we be arguing for a greater presence of art there? We - Arte Urbana Collectif, an artistic collective and non-governmental organization based in Sofia, Bulgaria - believe the answer to be yes, and in the following conversation, we will attempt to demonstrate why.

During the first forum exploring the topic of film education in schools recently organized by Arte Urbana Collectif (at the Institut Français de Bulgarie, 21-23 June 2019), the producer and film festival organizer Nina Pehlivanova shared a presentation 
('Cinema in school-policies from the past and dispositive in the present'; Pehlivanova, 2019) focusing on the 1927/8 Bulgarian law for 'school and mobile cinematographs'. According to this law, schools and people showing films should 'aim to increase the knowledge of young learners and to increase the understanding of the population in the field of science and arts'. Another aspect of this law was that, when a new school was planned to be built in a village or small town, it was obligatory that the school be provided with a cinema hall or white walls that could be used to screen films. From a present-day perspective, it seems incredible that in 1920, the Bulgarian Ministry of Enlightenment held a conference devoted to exploring the possibilities of using cinema in educating students about film in school settings. Indeed, it was in 1920 that the first school cinema opened in a sports hall in a high school in Sofia. Here - a far cry from how things stand in 2019 - cinema was integrated within the school curriculum, with students discussing various topics related to films they had seen projected during the school day.

During the communist regime in Bulgaria, these film education programmes were discontinued, and cinema was largely used for the purposes of political propaganda. While there was still a strong network of cinema halls around the country, these showed a government-approved programme of Bulgarian and Soviet films, alongside some Western European cinema considered to have a left-wing orientation. Most of these cinema halls were subsequently closed, sold or destroyed after the collapse of the communist regime. In 1963, Bulgaria had more than 3,500 cinema halls; in 2018, there were only 69 with 226 screens, located mostly in larger cities.

At the beginning of the 1980s, the state-led programme Bulgarian Cinematography initiated a degree of film education activities in schools. A team of cinema critics selected approximately a thousand films, creating two collections accompanied by annotations and short reviews of the selected films. In the same period, the National Academy for Theatre and Film Arts in Bulgaria (NATFA) began a special programme dedicated to educating cinema teachers to become exponents of cinema as an art form in the Bulgarian school system.

After the fall of the communist regime and the changes in Bulgaria's political system in the late 1980s, however, mass emigration, as well as the ensuing economic crisis, led to a collapse in the educational sector in general. Hundreds of schools were closed, particularly in small towns and villages, and - alongside tangible teacher shortages - educational curricula have since been undergoing many changes without a clear direction or a national development plan.

State education, administered by the Ministry of Education and Science and the Ministry of Culture, has - in our opinion - tended to adhere to a strict, conservative status quo, allowing for very few innovative ideas related to artistic education that might risk burdening its bureaucratic apparatus. In addition, there would seem to be a notable lack of cooperation between different organizations - between public authorities and broadcasting structures - and a general lack of understanding of the importance of film and arts education in general. Within this context, artistic subjects and disciplines at primary and secondary school levels have tended to be considered non-essential, and are often neglected in favour of others deemed more important.

Outside the governmental sector, however, there has emerged a series of projects and initiatives looking to address the lack of film education by means of local cinema clubs, online platforms for short films, and programmes of free screenings of European films followed by discussions with younger audiences. While there is at present no overarching national plan for education in artistic disciplines, those of us in 
Arte Urbana Collectif have encountered what we believe to be an urgent need for it through our ongoing work.

Arte Urbana Collectif - an artistic collective based in Sofia, Bulgaria - was founded in 2016 by me - project coordinator and film programmer Ralitsa Assenova - and theatre producer and director Dimitar Uzunov. We were later joined by other artists and cultural workers from Bulgaria. Since then, the collective has organized cultural events such as film festivals, educational forums and theatre performances in Bulgaria, aiming to help foster an artistic and cultural dynamic in the country with an international perspective. One of Arte Urbana Collectif's key objectives is to develop forms of access to the arts for young, difficult to engage audiences, and thus to initiate projects related to the educational sector and promote the role of art and culture as a political and social corrective.

Arte Urbana Collectif's film education initiatve - Cinema in School - encompasses several projects. The first is the Meetings of Young European Cinema Festival, a festival created six years ago and dedicated to young audiences. This event aims to support the presence of high-quality contemporary cinema in Bulgaria through screenings, masterclasses, workshops with film professionals, and other film education initiatives for young people. During the past six festivals, more than fifty screenings and discussions have been organized for young audiences, and young people have had the opportunity to moderate discussions with film directors and film-making professionals, and to create the festival trailer.

An important project that has influenced and fed into the development of Arte Urbana Collectif's Cinema in School programme has been CinEd: European Cinema Education for Youth, as initiated by the Institut français in Paris and supported by Creative Europe/MEDIA and Sofia municipality in Bulgaria. CinEd aims to facilitate the implementation of film education activities for young people across Europe using its cined.eu platform, through which one can organize free public screenings both in schools and in other settings such as libraries, cultural centres and cinema halls. Screenings are enabled through the easy transfer of digital files. The films included in CinEd's collection share certain aesthetic qualities, allowing for a common pedagogical approach. The project's partners - A Bao A Qu (Spain), Asociace českých filmových klubů - AČFK (Czech Republic), La Cinémathèque française (France), GET Cooperativa sociale (Italy), IhmeFilmi (Finland), Institut français (France), Os Filhos de Lumière (Portugal), Societatea Culturala NexT (Romania), Meno Avilys (Lithuania) and Arte Urbana Collectif (Bulgaria) - are motivated collectively by the question of how best to present and transmit European cinema in a manner that prioritizes cultural, historical and linguistic diversity.

CinEd's platform provides subtitles for each of its films, and multilingual pedagogical tools for teachers and students to accompany the screenings, and to help run activities before and after the films have been shown. From elementary to high school, several pedagogical activity pathways are provided to help teachers and mediators introduce the films to young audiences and develop their taste in cinema. CinEd also offers training for teachers that has been developed within the programme on a European level. The Ministry of Education now certifies this training in Bulgaria, allowing Arte Urbana Collectif to engage more teachers and help assist them to engage in innovative film education work on a national basis.

Another transnational European project offering support for understanding, practising and transmitting cinema in schools is 'Le cinéma, cent ans de jeunesse' (CCAJ), coordinated by the Cinémathèque française. As a programme, CCAJ (which has been explored elsewhere in the Film Education Journal by Chambers $(2018$, 2019), 
Aidelman and Colell (2018) and Donald (2019)) allows groups of young people between the ages of 7 and 18 from different countries to explore cinema both as audience members and film-makers. Participants have the opportunity to discover cinema through a practice-focused approach that each year revolves around a different 'question of cinema' (in 2016/17, 'Play'; in 2017/18, 'Place'; in 2018/19, 'The situation'). The project also provides a specially developed methodology and resources that turn the process into a significant experience for children and comprise a pedagogical approach that is also applicable beyond the context of cinema. Every June, at the end of the school year, films from each participating group are screened publicly at the Cinémathèque française, in front of participants brought together from all over the world.

The implementation of both CinEd and CCAJ has proven important for Arte Urbana Collectif in helping foster an increased presence of cinema in schools in Bulgaria on a national level, and also among institutions and representatives of the non-governmental culture and education sector. In our experience, cinema has an inexhaustible potential as a vehicle of inclusion for children and young people in the field of education. In our work, we have frequently witnessed how studying film at school provides all students, even those considered 'underachievers' in the traditional education system, with the opportunity to articulate what they perceive on the screen, as well as to develop their own resources and means of filtering the images surrounding them constantly in their everyday lives.

Arte Urbana Collectif's film educational initiatives have been explicitly developed to enable us to cooperate with teachers, who are often overburdened with administrative procedures that in turn limit their opportunities and ability to engage with experiences of creativity. Fortunately, we have found that there is an increasing number of educators willing to take up the cause of passing on the art of cinema to their students, using the resources we are able to offer.

It was these sorts of film education activities that led to our meeting with Daniel Simeonov, an English teacher at the Neofit Rilski school in the village of Dermantsi. The school where Daniel teaches is located in the north-western region of Bulgaria, one of the poorest areas in the European Union, where the population has drastically reduced in recent years. Daniel is an enthusiastic exponent of film education, and is enthusiastic about his role, leading a voyage of discovery into the world of cinema for young cinephiles. Before deciding to become a teacher, Daniel studied film directing at university. Neofit Rilski's primary school staff consists of 19 teachers and a principal. Currently, 200 pupils are being taught in ten classes, including children from the neighbouring village of Aglen, Daniel's birthplace, where the local school has closed.

Over the two years of our collaboration, what has struck both us and Daniel is the fact that pupils who have been willing to deepen their knowledge of film through watching, discussing and making their own films have also achieved on other cultural and educational levels. As a result of their engagements with film education, many pupils seem to have discovered their own unsuspected talents and new opportunities to get to know the world they live in, along with its rich sense of otherness.

\section{Ralitsa Assenova: How would you describe your first encounter with cinema, and what is the place of cinema within the context of your professional life?}

Daniel Simeonov: I need to go back in time, a lot. It was in the movie theatre of the village where I spent my childhood, in the village of Aglen. Before the fall of the communist regime, there were cinemas everywhere throughout Bulgaria - there was a film venue in every village and hamlet, and there were regular screenings, three times a week. I remember one of the first movies I ever saw was sex, lies, and videotape 
(1989, directed by Steven Soderbergh). The magic of the dark hall, the screen that transfixes you, the smell of the artificial leather with which the seats were upholstered I will never forget this impact. Today, this room exists in our chitalishte, where the seats are the same, so when I go there, the memory of my first entry into the cinema emerges again. Let me just clarify that chitalishte is a typical public institution in Bulgaria, specific to our country, best described as a community centre with a library, which offers also a variety of cultural and educational activities, mostly in the field of the arts.

Otherwise, one of my later and more conscious encounters with the cinema was in Cherven Bryag. I went there with my volleyball team. It is how I saw Jane Campion's The Piano (1993). It was not my intention to choose this particular movie. I did not know who Jane Campion or Holly Hunter were, but seeing that The Piano was being screened, I went without thinking - the only one from the entire team. And then I realized that this is something that deeply excites me, and would surely excite me in the future too, hence our meetings became more and more frequent.

I have to admit that I have not entered the big world of cinema through the classics or auteur cinema; I discovered these later. First, I started being interested in what is happening in Hollywood. And because I come from a very small place, Hollywood was an impossible dream - this world was too far away and too vast. Cinema remained my secret dream, as I began studying philosophy at university. But Hollywood has always attracted me, mostly as a teenager; maybe that is why I tried a work-and-travel exchange in the US. When I came back, I was changed. I got more courage and decided to put a stop to my philosophy classes; so I began to study directing.

\section{RA: How did you come to the idea of teaching cinema at school?}

DS: Maybe I should tell you first about how I got to the idea of teaching at all. I had never dreamed of being a teacher, but I have also never excluded the idea that this profession might play a part in my life. While studying at university, I understood that becoming a film-maker is not the easiest task of all, and moreover one that does not rely on talent only. I found that film studies, as part of the 'science of cinema', is also very interesting to me.

So I started working in a big corporation, burned out, went back to live in a village, and decided that what I have to give to the world is being a teacher. I started teaching in primary and lower secondary school. The first year I did not think about any possible ways to integrate my film interests into students' interests, because I did not believe it was possible.

The solution came with the Zaedno $v$ Chas programme or Teach for Bulgaria, part of the Teach for America initiative, where young professionals are involved in public education in order to ensure equal access for everyone on a global scale. This is how 1 got acquainted with some side initiatives and projects. One of the programme leaders mentioned the Cinema in School initiative, and so I approached the coordinators.

I got in touch with Vassilena Badjarova and Ralitsa Assenova, and thus cinema invaded our school. And not only my classroom, but also all the classrooms I have access to, one way or another, as well as the entire Teach for Bulgaria community and beyond.

RA: Can you tell us about the Film Academy you organized immediately after initiating contact with Arte Urbana Collectif, as well as about some of the screenings from this event in particular?

DS: While participating in Teach for Bulgaria, for the programme duration of two years, we could launch a special summer project to engage children with something 
that is useful and interesting to them. After meeting Vassilena and Ralitsa, I thought it would be great to have a Film Academy, a mini festival of sorts, to screen as many titles from the CinEd platform as possible. We expanded in terms of venue, so the event became part of a bigger project called Everest Summer School. With children from four neighbouring villages as an audience, all working on extra-curricular activities tackling their difficulties in class, we screened the first films from the CinEd collection.

For one of the screenings in the village of Belentsi, where the summer school activities took place in the municipality hall, a special room was provided (see Figure 1 and Figure 2). I went prepared with the projector and a laptop, ready to show Back to School (Rentrée des classes, 1956, directed by Jacques Rozier). Children there are from an extremely underprivileged social environment, and their outlook is informed by the fact that the greatest challenge in their lives is the socio-economic one. Some of them even had difficulties speaking proper Bulgarian.

My first impression going there was that the children were hyperactive - running around, constantly asking questions; they were uncontrollable to some extent. I asked myself, 'How is this screening going to happen? And what are we going to talk about?' This world of cinema and framing, as well as the message I wanted to address, seemed far from reality. I waited for them to finish some work, then I started installing the projection equipment. That is when I realized that there was actually no screen! I had taken everything - a projector, a laptop, speakers - but in this communist-era hall plastered with brown panelling, there was not a white wall where we could possibly screen anything. It occurred to me that we could cover up this brown-yellow wall with white A4 sheets of paper, so we could make a screen on which to project the film. This led to an interesting task for the kids - to work together to help me to do something, something that brings a surprise: something will happen on this wall. Since the film was black and white, I had this false stereotype that when they saw the black-and-white footage, kids would get bored. On the contrary, the moment the movie started, some odd hypnosis settled in. I had assigned a few exercises before the start of the film for example, to predict what would happen to the protagonist, by showing them a photograph of the boy in the film, René. By and large, it was very easy for the children to identify with the boy's character, his freedom, swimming in the river, which they do near the village too. The same for René's rebellious stance, which suggests that the school is a place not yet recognized as theirs.

The film was received with enthusiasm, and afterwards we held a long discussion. I only guided them with questions: Which scene struck you most? Why at this point was the camera placed there or was moving that way? What characterizes the protagonist? And children who had no clue about multiplication tables, or would not be able to identify the protagonist in a poem, gave absolutely adequate answers. We talked about the story in the film, and why things are being portrayed in a particular way to affect the viewer. They also discussed the important moments of the storyline, and specifically why the protagonist puts the snake back into the river - 'Because it is his friend, and we love our friends and we want them to be happy and free.' This screening reinforced my attitude about why it is important for children to watch cinema, and especially notable European auteur cinema, not just animation or something shot specifically for children. Needless to say, the questions after the screening were: 'When will you come again?' 'When will we watch another film?' 'Which will be the next film?' 


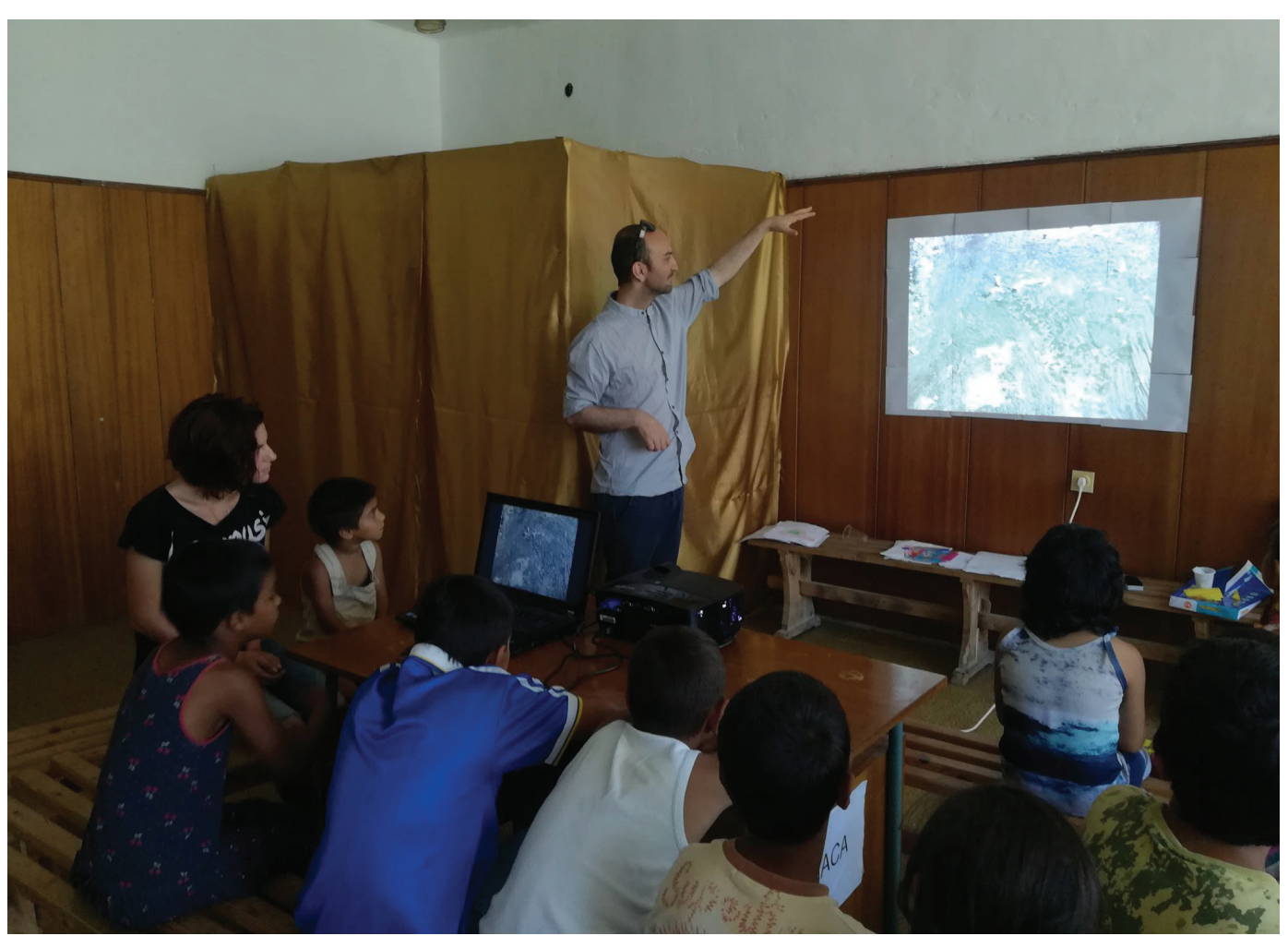

Credit: Arte Urbana Collectif

Figure 1: Screening of Back to School in the village of Belentsi

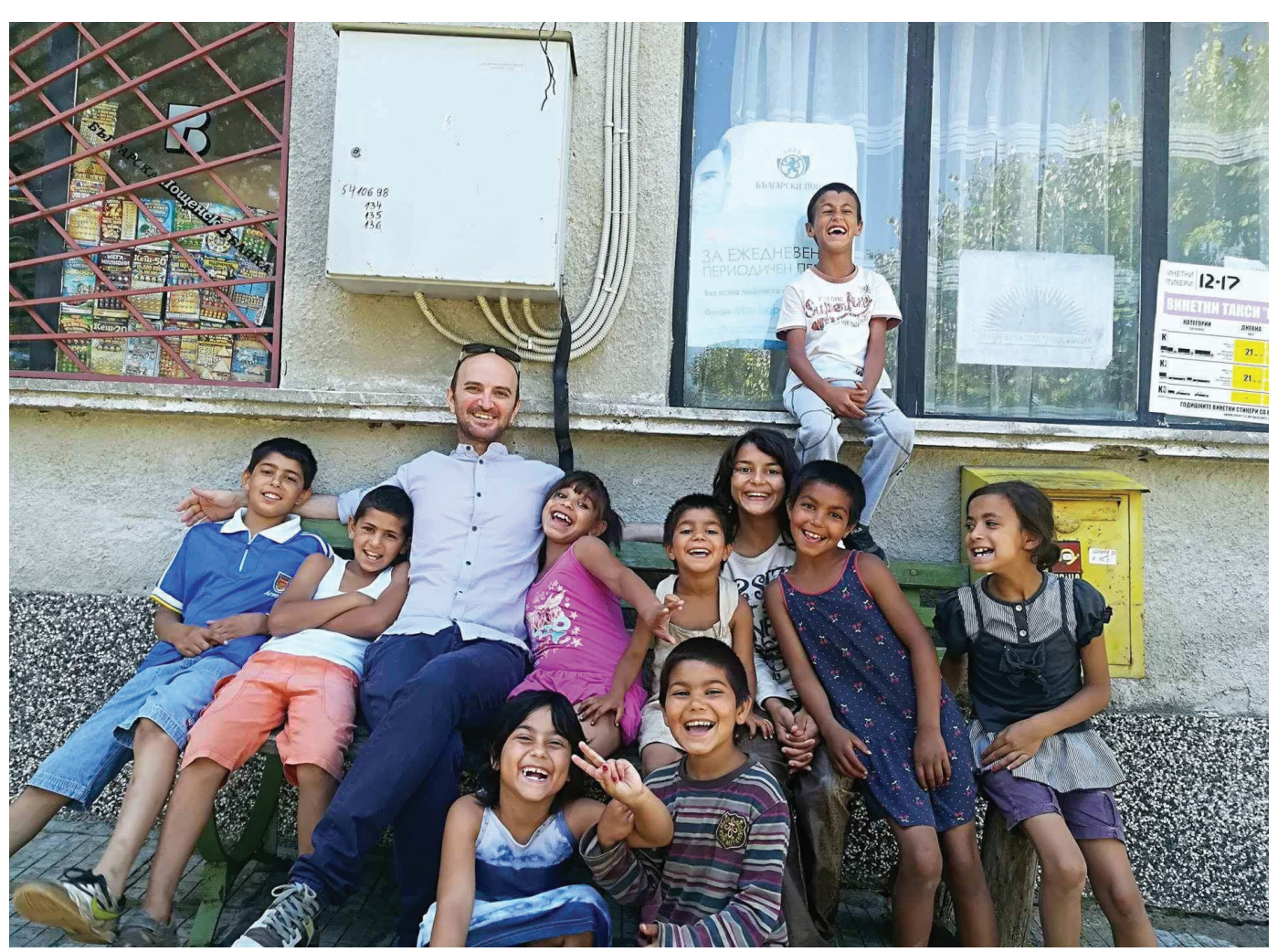

Credit: Arte Urbana Collectif

Figure 2: After the screening of Back to School in the village of Belentsi 
RA: In your experience, how does cinema fit into an environment characterized by socio-economic disadvantage? And what is your students' viewing experience beyond the lessons you teach them, or the films you show them? Do they have access to this type of auteur cinema we talk about, which we love, cherish and want to make popular among young people?

DS: My master's dissertation was precisely on film education at school, and how to use narrative visual forms so that children can understand the meaning as a whole, to understand the story. Paradoxically, it seems that children with sociocultural or socio-economic deficits - children who are 'underachieving' students - they appear to be more active during our film meetings than the others. This is perhaps because in these activities there is no strict evaluation matrix or the requirement for any particular, specific knowledge. In such cases, the children react spontaneously to the film, and even without the proper terminology, they find their way to the essence of what they have experienced in front of the screen. For the same reason, 'successful' students feel some discomfort amid such a pedagogical environment that is new to them; they cannot guess which might be the right answer, and they are afraid of giving the wrong one, because a mistake for them equals failure. These meetings with cinema art give a lot to all pupils: to some - growing up, overcoming themselves; to others - the opportunity to shine, which is otherwise impossible in the traditional educational setting. This is why I see these pursuits in cinema as an opportunity for self-development.

As for your second question on kids' access to cinema, I would like to clarify whether you refer to film in its pure form, or to all narrative forms, stuff they download from the internet, watch online or on television.

RA: In that case, let's talk about the moving image in general.

DS: I may sound prejudiced in what I am about to say, but I think that to a large extent this is one of the main problems for my students when it comes to being adequate to the world they live in, because the moving images they encounter are not film images, they are not 'standard' images, even Hollywood images.

My students like horror films as well, because these are in sync with their basic, primitive instincts, in which good defeats evil. They watch soap operas, not Western or Latin American, but Turkish or Indian, which are extremely stereotypical, for example concerning the woman's role in the family. This negative impact is being multiplied in their behaviour at school. I find this situation potentially dangerous, and here one can sense the state's shortfall when it comes to a general media policy.

RA: How do you think the process of watching and perceiving films relates to the process of film-making? What were the challenges for the creative process you had with your students within the CCAJ programme framework? Could you elaborate on your preparation, the shooting and your methods - especially with regard to the acting, which I'm aware made such an impression on everyone who saw your film?

DS: For me, the greatest film school comes from simply watching films, and I hope I have conveyed this belief to my students as well. There are many cases in modern cinema - from Tarantino to Tom Ford, who also make movies without having studied the craft academically. 
If you feel a certain way after having watched a particular scene, you start asking yourself questions: What was the director's approach, so that I feel like this as a viewer? What was shown or not shown on the screen, so that I feel like this? This all urges you to say, 'I have a similar sensation; I want to express it somehow.'

At first, the children were slightly sceptical. We started working with excerpts from different films. We watched dozens of them, did exercises in which we watched a certain scene without sound, and we were thinking - what sound, what kind of music we would put there; and then, vice versa - we listened to the sound of a scene where a character is persecuted and imagined how it might be realized visually by a director. Thus, the children gradually started to comprehend the relationship between active viewing and film-making.

The important thing was that they managed to find the connection, especially children who have some form of affinity for the visual, who are interested in references, references to images and how they affect us. Then we gradually started going into the preparation of our final film for CCAJ.

First of all, we made a plan for the whole process. This is a very important step for our conditions and sociocultural context, but also for their age. We discussed the script, but also what kind of film it would be: the costumes, the sound, where we would shoot, how we should shoot it. We had long discussions, and emotional ones, too, because it was difficult for them to work as a team - this is a challenge in Bulgarian education in general, perhaps due to excessive individualism. Finally, for the script, we decided that everyone would be assigned the task of telling a story, as defined by CCAJ's 'rules of the game' on the topic, and I insisted on the fact that the story must not be just told, it has to be in written form. We had a very long session where everyone read their stories; some of them were insanely long! On the blackboard, I noted down all the ideas that seemed valuable to us, and after a long process of filtering and conversing, we came to the concept of making a film about the end of the world.

Afterwards, we distributed the roles in the process: who will write the script, who will make the storyboard, who will think about the costumes, who will be responsible for the locations ... Everyone wanted to participate as an actor.

We started rehearsing, but at first the result was very theatrical. Students approached acting as if it were a play. Then I changed the strategy and decided that we would do no more rehearsals. We asked the children to read their lines, to comprehend them, and to learn them, as the shooting period was approaching. During the filming, there were actors who wanted to stick to the original script, but we told them that the exact words no longer mattered - the idea was to be as relaxed as possible, natural and authentic in the creation. Perhaps this is why we have succeeded somewhat - we wanted the acting to be intuitive and improvised, which is not always easy for the students (see Figure 3 and Figure 4).

The shooting process itself was wonderful, and we had a great team of helpers and film professionals who supported us with equipment and logistics. The presence of the adults motivated the students even more, and what surprised me, personally, was their extraordinary discipline. The set had a huge impact on them; when they saw everything in one place - camera, microphones, equipment, costume bags and the rest of the crew - they felt how serious cinema is, just as with their first experience of it. 


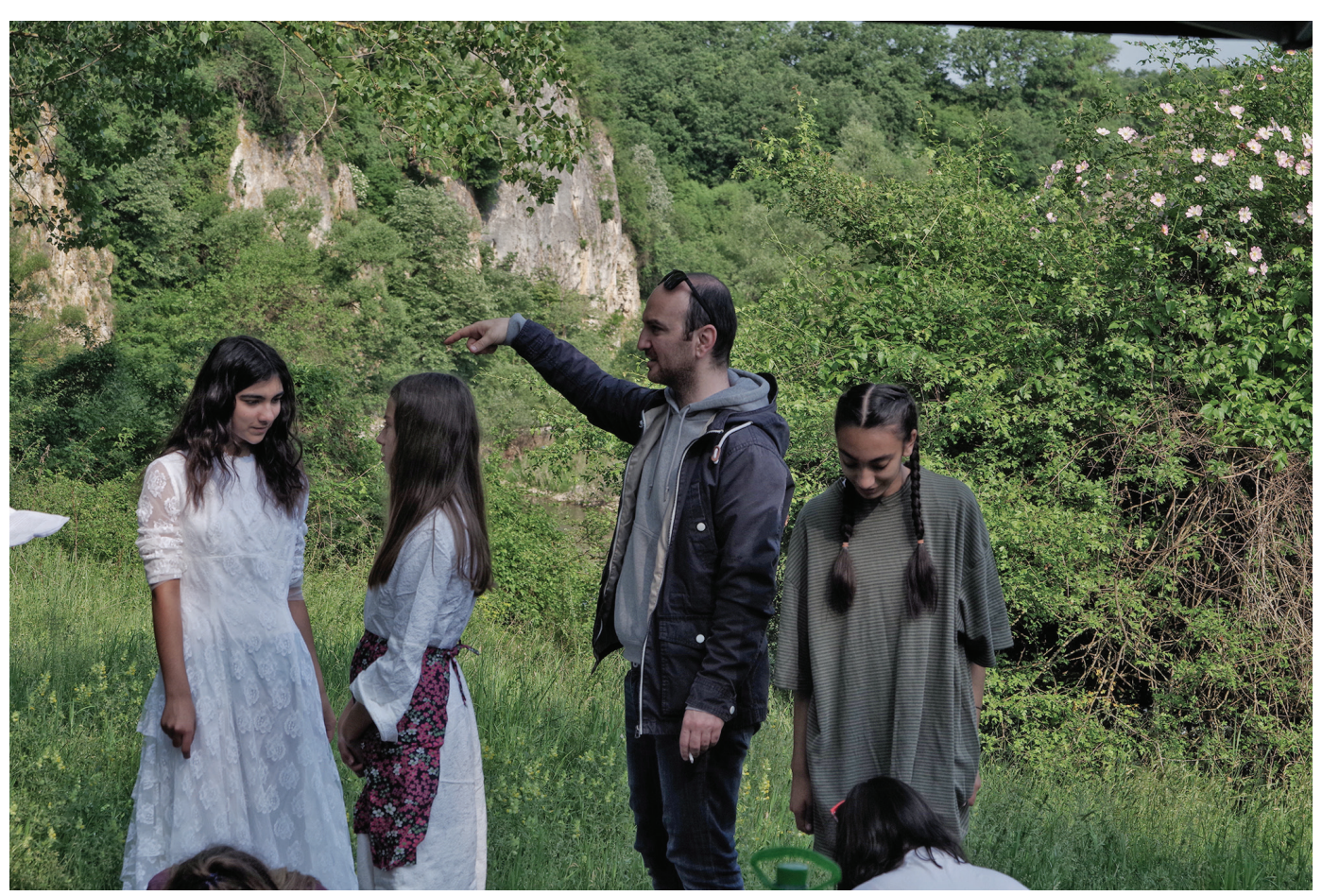

Credit: Arte Urbana Collectif

Figure 3: The shooting of $9+1$, filmed for CCAJ 2017/18

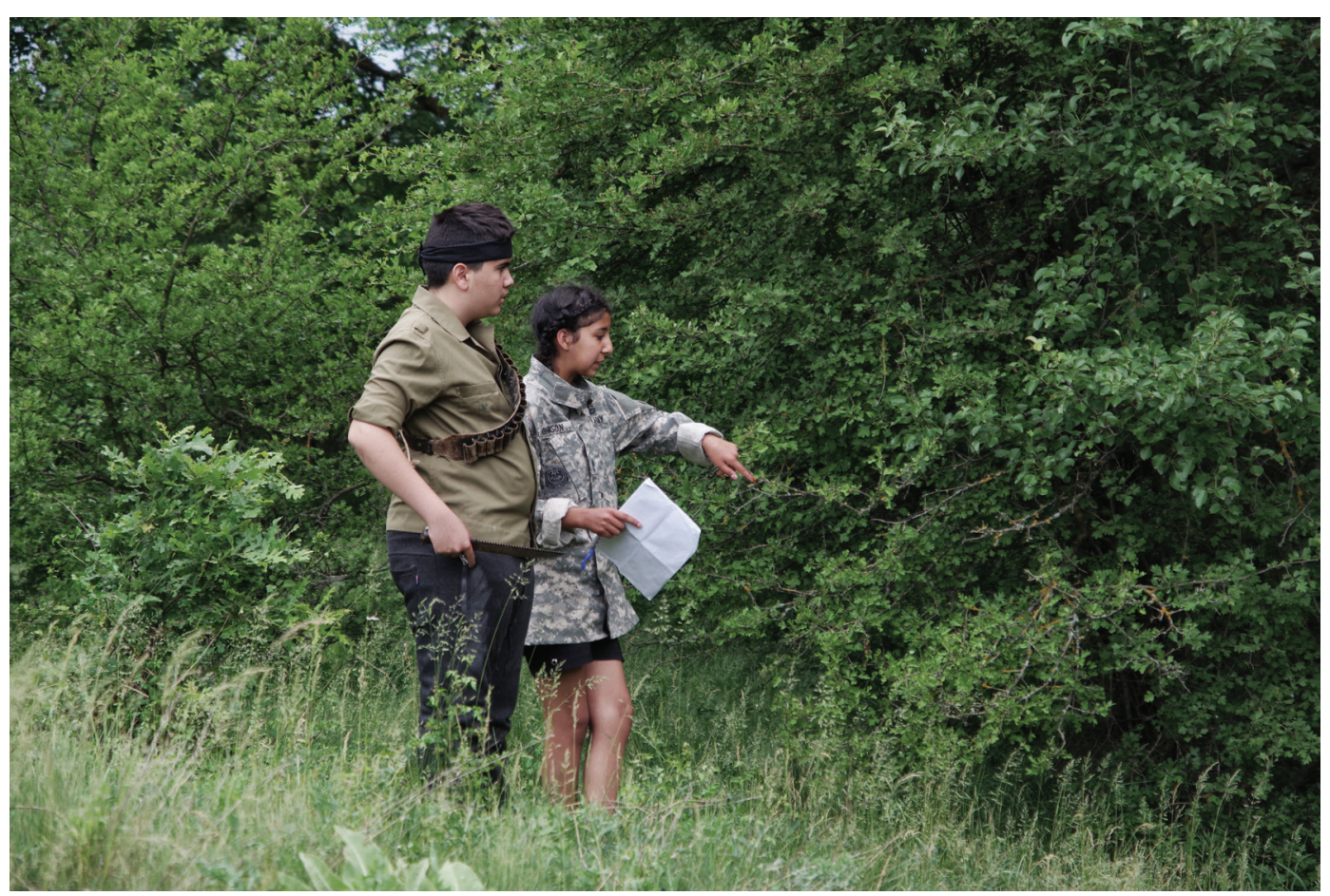

Credit: Arte Urbana Collectif

Figure 4: The shooting of $9+1$, filmed for CCAJ 2017/18 


\section{RA: Does the cinema change the school hierarchy and the teacher-student relationship?}

DS: Of course it does, definitely. As I said before, for the pedagogical process of film education to happen, the traditional teacher-student relationship is impossible. I would not say that this a problem for me, but many colleagues look at me differently, because thanks to the cinema we do things they do not have access to, we let the students experiment and express extreme, unconventional opinions, we let them make-believe, dream, so this all makes the kids closer to me, on a purely emotional and personal level.

This is a problem for my other classes, when I teach English. Not all kids are part of the cinema studio, and my students are still little, so they have a difficult time grasping the boundaries of the traditional and the extra-curricular learning processes, the boundaries of different requirements and programmes. But in the cinema, it is definitely important that this relationship between a teacher and a student is not the ordinary, the banal - through film, they both learn.

RA: You spoke a bit about this, yet if you feel like it, you can expand on the subject - does the cinema change the place of some students who are lagging behind in the traditional educational system, yet are actively involved in the creative process?

DS: Maybe I am biased, but a colleague of mine and I commented recently that this is something that should be taken into serious consideration, and especially due to the fact that it is the students who embrace with great enthusiasm the possibility of including artistic forms of expression in the standard education.

There was an example a few days ago when, in response to a competition brief, our students composed a rap song. We had to shoot a video for the competition. We had to organize it all within one day, and these four children trembled with excitement for the preparation, creating a concept with specific proposals that are relevant to the film medium - where stands the character who will be in the frame, where do we put the camera, how will it move, at what point will another character come in - which is directing per se. They were extremely excited about the shooting process. Then they saw the video, asked once when the contest was, but nothing other than that - not even what or whether they would win - which means that it is the process itself that excites them and transforms them. Especially for the students who are not doing so well in class - this is their way of self-expression, this is their way to be equal with the others, with the world.

RA: The fact that pupils are already familiar with images - because of the manner in which they are permanently watching, photographing, sending images - is this a problem or an advantage in terms of education in media literacy?

DS: It is ambiguous. As a rule, to me, it is a problem because this carries on the complications of non-aesthetics. First, most of the images that they make, even selfies, are copies. They are taken from a role model who stands in such and such way, who makes such and such face. This means these images lead to nothing but a constant copy without originality, or a process of creativity.

Nevertheless, if this is harnessed in favour of the aesthetics of the image, meaning they even copy something that is aesthetically pleasing - it is the first step towards learning and education in aesthetic imagery. Unfortunately, they tend to copy the bad example. 
In this sense, if we watch a good film, with interesting acting, and can recreate some dialogue, it could have a pedagogical effect - the aesthetic need to experience or repeat something on a high level.

RA: The world is changing; how do films fit into the digital present of the young, and what do you think, therefore, is the place of classic cinema? By classic, I mean the 'hall-screen-viewer' setting, and how this relates to the other screens surrounding young people, and the way they process images. What is the role of the cinema, or what should it be?

DS: If I could answer this question with certainty, I would have been able to solve the cultural problem of Bulgaria [laughs]. The truth is that rapidly changing images are everywhere around us, and there is nothing we can do to stop the process. Still, I am convinced that the role of cinema is crucial here, and the same goes for these film-related activities with the students, so they can build their own tools, or a set of tools, in order to filter meaningful images with valuable information and a high level of aesthetics.

The classic set-up you mention is extremely necessary for children in small settlements, because many of them have never experienced the hall-screen-viewer configuration. This disposition you are talking about, my students experienced it for the first time at one of the festivals where we presented our short film, as they were looking at themselves and their own creation. It is a very strange experience - to go to a cinema (and the three children with whom we were at the Varna festival had never been before to a cinema), and in the big hall of the Congress Centre, when the lights went out, they met not only with the big screen, but also with themselves, in the form of cinematic images.

They need this; they need to watch a film without being interrupted. We need that. And here comes the problem with the lack of film venues; in many places in Bulgaria, even in larger cities, they are absent. This encounter with the cinema is the most authentic, the most real, the most meaningful, the most cathartic, as we share the film with others in the theatre who come with the same purpose - to experience what the authors have created for us. This is part of cinema's ability to change and to influence.

RA: Is this perhaps the role of the school, of the teacher - to show children these films in their entirety?

DS: Even though it sounds very didactic, I show them the benefits of watching the whole film, so I hope that - registering and comprehending this idea of cinema - they will pass it on. Surely, the images will continue to flood us, but can we learn - because this is a continual learning - how to filter them, how to understand their meaning, their sense, by excluding the context of our personal taste?

RA: What are your personal criteria when choosing a film you would show and study at school? Is film selection related to building a taste?

DS: Yes, it is precisely this - showing films is about creating a taste and a relationship, not only with cinema, but also with art in general. I would choose a film that could shake up the students, reveal a new horizon, take them beyond their environment and their thinking, be enigmatic. After the screening, they need to ask themselves questions for a long time: 'I do not understand this, but it troubles me, provokes questions in me.' I would paraphrase Alain Bergala on the enigma that only the encounter with real creativity could bring (see Figure 5). 


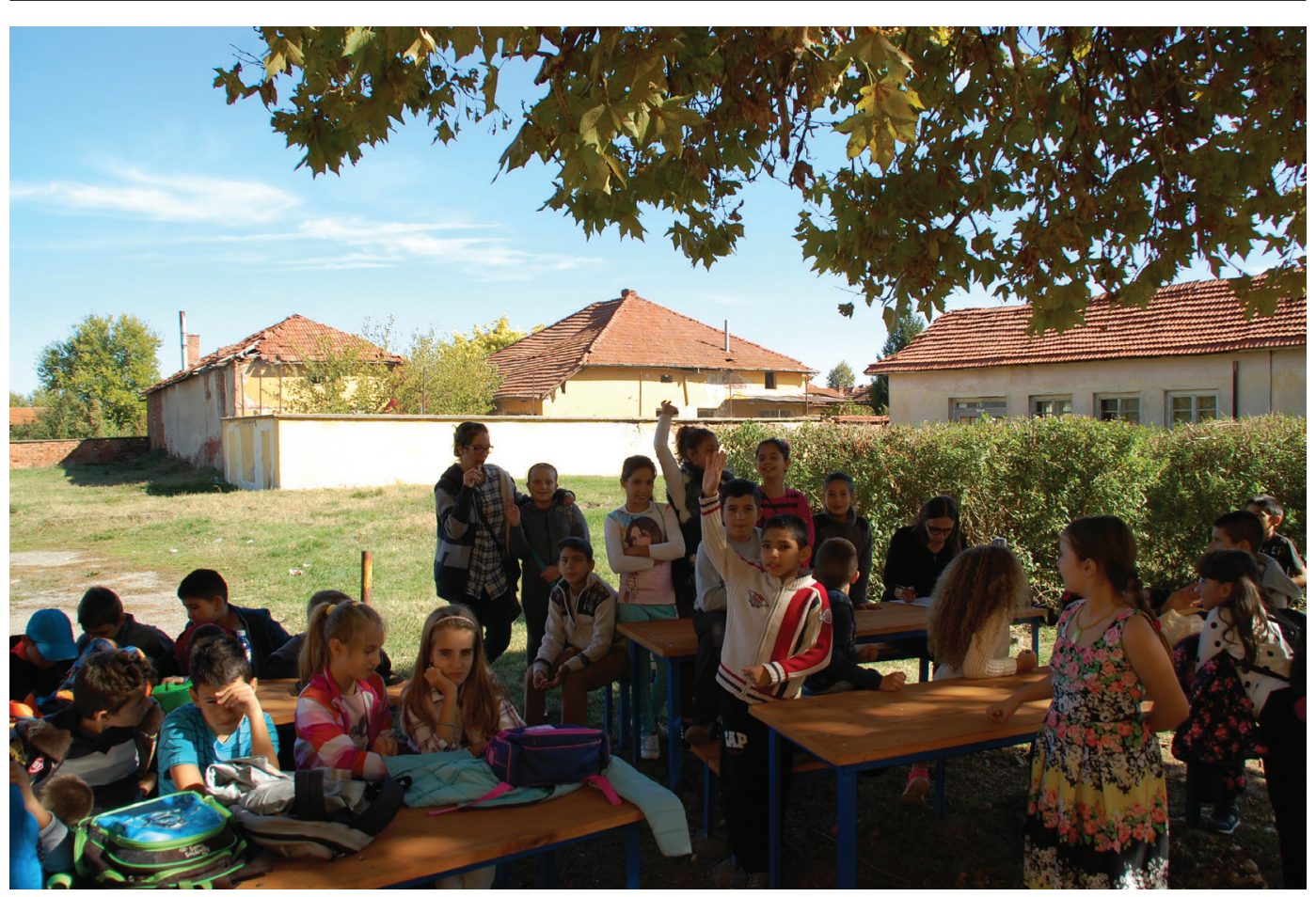

Credit: Arte Urbana Collectif

Figure 5: Discussion after a screening of The Spirit of the Beehive (1973, directed by Víctor Erice), held with students from primary school 98, Saints Cyril and Methodius, Sofia

\section{RA: How do you handle the screenings in terms of equipment and logistics? What problems do you encounter?}

DS: Technically, in the twenty-first century, it is not that complicated to have a screening - we need a projector, a computer, a screen and a dark room. The biggest problem is to darken the room. Both the network of cinema venues and the chitalishte system that owns multipurpose halls in Bulgaria are almost non-existent. In the winter, even if the local chitalishte is open and there is a screen, it is not possible to organize screenings, because there is no heating in the building and no one could withstand an hour and a half below zero, even to watch a Truffaut film.

In that case, we could make the screening at school, in a classroom, but there is the problem of light. Only in a completely dark room can the projector really imitate the older cinemas, the rays pouring onto the screen with all the bizarre lights that took our breath away when we were little, sitting in the back row, and holding up our hands in front of the light beams to see our hands on the screen.

RA: What are the tools you found yourself, or that other programmes have provided, which help you to teach film?

DS: What I have as a resource is the CinEd platform, with the films and the pedagogical materials to accompany them, which give me great ideas for teaching - what exactly we can put together for the students as an active task, beyond the viewing, so cinema is not just some activity to fill in school time but an active pursuit, an event.

The tools I use are very often improvised to some extent. The educator, who is supposed to do this and who will showcase films, should know that each screening can go in a different direction, and there is nothing to be afraid of. The post-screening 
discussion can often surprise, but he or she should not experience any discomfort or have any expectations of how it would be.

I like the suggestions on the CinEd platform for pedagogic work after seeing the films - such as creating a poster other than the one we see before the screening (if any), or writing a letter to the director or to a protagonist ... There are a lot of possibilities, and I believe this is the most liberating part - to improvise when you are a teacher who has previously studied the film.

\section{RA: How did the film education training in which you participated help you design your project work? What would be the ideal form of teacher training according to you? What would be the ideal elements and learning process?}

DS: The most important element is the availability of teachers who have commitment to the subject.

My case is a bit different, as I have some background in cinema, and it is easier for me to connect with this pedagogic element of how to talk about cinema.

The training, in my opinion, must consist of activities around watching and talking about films, with a balance between images and words. In CinEd's training, for example, we saw Pierrot le fou (1965) by Jean-Luc Godard, which is mandatory for those teachers who decide to engage with cinema at school. By getting acquainted with this film, they are pushed into this enigmatic zone, which we want the students to experience.

The ideal training for me would be a balance between watching films, excerpts of films, commenting and sharing practices, exchanging experiences of what happened during a certain screening, and how students responded (the reactions can be very different). It is very important during this training for the teachers to get rid of the evaluation concept - not to reproduce in cinema classes the 'I'll give you a certain task and then tell you who did it best' model.

\section{RA: Do you think cinema can be a school discipline? If so, what would be the procedures? Should students be formally evaluated, and - if yes - then how?}

DS: A very complicated question. Yes, cinema must be part of the school system. Yet, at present, with the current status of the school system in Bulgaria, even being part of it as an optional discipline, for example, would immediately mean cinema enters the administrative framework of allocations of duties, curricula, products, exams, tests, et cetera.

Maybe within the current education system, it is better for this activity to be present in extra-curricular form. Inclusion of cinema in the classroom as an art, as a way of building a taste, of attitudes towards the world, is directly linked, unfortunately, with a change of the education system, a change of its concept, which is much harder.

Currently, the class periods are 40 minutes, so purely logistically it would not be possible, because the film should be seen in its entirety. For the grades, I am not sure how and what would be evaluated. As a school subject - the history of cinema - to talk and then ask who created this or that film, or give a definition of the French New Wave - this is absurd!

The other option would be to introduce cinema as part of Bulgarian education, only not with regular classes every week, but with a special schedule, another vision, a combination of film viewing and out-of-school practice. No evaluation, just credits, for example, to formalize it in some administrative form.

Judging from my experience, the informal character must be preserved, so it all makes sense and has an impact on the children, so they can discover films in an 
authentic way, and so that this can actually be a motivating tool. Because otherwise it will become yet another class.

\section{RA: What should be the place of film-makers and industry professionals in schools?}

DS: First of all, I would say that the cinematographer with whom we worked on our film's shoot felt enriched by communicating with the children, through cinema, by making cinema in this environment. She is eager to come back, show films and take part in other practical activities.

My opinion is that cinema professionals do not do enough to feed back into the educational process, to the educational process in the arts. I think everyone has this responsibility - being already well-educated, involved in this art world - to 'pay it forward'.

\section{RA: In your opinion - cinema, interpreting images, creating images - could this be an alternative pedagogy?}

DS: Undoubtedly, the data I have confirm it. I can give an example of a literature text that sixth-grade children need to read and then talk about - a [Bulgarian] National Revival writer, let's say. The purpose of this pedagogical approach, to read the text and discuss it, is not just for the students to understand who Dobri Chintulov is and what he wrote - yet again this is also important. Still, the real pedagogic element, I would say, is for the kids to think about the text's meaning and what it represents. I can say it directly: for the majority of sixth-grade children this is impossible.

Anyway, I screen Back to School for them, and ask them the same questions aiming at analysis, starting from purely factual questions and descriptions of what they saw on the screen. There will be no student who cannot interpret and cannot participate. Even students who cannot read or count can give an autonomous answer to the question: 'Why does the protagonist drop the snake back into the river at the end of the movie?' If I ask a specific question about the meaning of a character's action in the context of Dobri Chintulov's oeuvre, the answer will be 'I do not know.'

It is surprising what levels of film analysis we are reaching with students, so yes cinema can be an alternative method of studying.

RA: What are the shortcomings of film education within the current Bulgarian educational system? What should be the role of the Ministry of Education, the Ministry of Culture, the Regional Inspectorates of Education, and what is it in reality?

DS: I have not noticed an adequate attitude towards artistic education at school, perhaps because there is some misunderstanding at institutional level about why this is so important.

In philosophy classes, there are films that can be watched to enable kids to discuss philosophical questions, and this I applaud. I also applaud the notion that films can teach us about history. It is not bad to get cinema involved in some of the school subjects. But this is not our idea, our ultimate goal, in order for cinema to find its place as an art.

In small-town schools, we are not talking about music as an art, there are problems studying fine arts. There are many small places where the music or the fine arts teacher is from another subject - such as a geography teacher - but he or she takes two hours of fine arts because the lessons are few in a settlement like Dermantsi, just like in Aglen - there is no one who can come and work for just several hours a 
week. And this teacher, who is further involved in these disciplines, cannot adequately fulfil the teaching task or use it for other needs.

There is certainly a possibility to set up some sort of logistics, where one peripatetic arts teacher visits several schools in a bigger area, but this requires a real policy in this regard-organizing modules, changing the programme ... This is not the case in Sofia, where schools are big and have enough classes on these subjects, and hence can afford a separate teacher.

\section{RA: What are your film education proposals for our time?}

DS: It is very complex, because in Bulgaria this is linked to a national infrastructure. It is connected with a huge project, with legislative or normative changes to prioritize, to put the arts in the foreground. I do not like to say it, but it is really important to change the current system. Because the efforts we make from within will reach a certain number of students, yet will stay cosmetic and at a superficial level, whereas if we have systematic thinking about how to teach cinema in the twenty-first century, on a national level, as a national strategy, this idea will be much more widespread. Otherwise, we will have CinEd, we will have another programme, we will get some results, we will see how useful it is, will include the chitalishte network as we do with CinEd - this is all great, just not enough if it is not being supported by the state. And why should it be supported? Because we have indications that it is important for our time, that it is working; we have indications that it is needed.

\section{Notes on the contributors}

Ralitsa Assenova graduated from the Sorbonne Nouvelle Paris 3 in theatre and cinema studies and from the University of Bologna, where she wrote a research paper on the work of Pier Paolo Pasolini. She has specialized in European cultural projects. For the past six years, she has been lead organizer and director of the platform Meetings of Young European Cinema and initiator of the Cinema in School programme of Arte Urbana Collectif. She is currently a PhD student at the National Academy of Theatre and Film Arts, Bulgaria.

Daniel Simeonov graduated in film directing from New Bulgarian University. He studied philosophy at Sofia University and world cinema at Birkbeck, University of London. His bachelor thesis project is the short documentary Close. He has directed student films and television commercials, worked as a film reviewer, and collaborated to organize film festivals. Currently he is a teacher in the village of Dermantsi. He devotes his efforts to promoting the necessity of the arts curriculum and disciplines in the Bulgarian education system, especially cinema.

\section{Filmography}

El espíritu de la colmena (The Spirit of the Beehive, ES 1973, Víctor Erice)

The Lesson (BG/GR 2014, Kristina Grozeva and Petar Valchanov)

The Piano (NZ/AU/FR 1993, Jane Campion)

Pierrot le fou (FR 1965, Jean-Luc Godard)

Rentrée des classes (Back to School, FR 1956, Jacques Rozier)

sex, lies, and videotape (US 1989, Steven Soderbergh) 


\section{References}

Aidelman, N. and Colell, L. (2018) 'Transmitting cinema: Some proposals for our time'. Film Education Journal, 1 (2), 147-62. Online. https://tinyurl.com/yajumwyf (accessed 26 August 2019).

Chambers, J. (2018) 'Towards an open cinema: Revisiting Alain Bergala's The Cinema Hypothesis within a global field of film education'. Film Education Journal, 1 (1), 35-50. Online. https://tinyurl.com/y2qzmgkt (accessed 26 August 2019).

Chambers, J. (2019) 'Exploring co-creation in practical film education from primary school to postgraduate study: Theoretical and auto-ethnographic perspectives upon teaching film practice'. Film Education Journal, 2 (1), 27-47. Online. https://tinyurl.com/y5n8wuv4 (accessed 26 August 2019).

Donald, S.H. (2019) 'Follow the yellow brick road: The passeur, the gatekeeper and the young migrant film-maker'. Film Education Journal, 2 (1), 48-61. Online. https://tinyurl.com/yy2oajpk (accessed 26 August 2019).

Pehlivanova, N. (2019) 'Cinema in school - policies from the past and dispositive in the present'. Paper presented at conference by Arte Urbana Collectif, Sofia, June. 